\title{
P02.180. Arts speech therapy influences heart rate variability indices
}

\author{
U Wolf ${ }^{*}$, U Gerber ${ }^{1}$, M Wolf ${ }^{2}$, S Klein ${ }^{1}$, F Scholkmann ${ }^{1}$ \\ From International Research Congress on Integrative Medicine and Health 2012 \\ Portland, Oregon, USA. 15-18 May 2012
}

\section{Purpose}

Previous studies revealed that arts speech therapy (AST) affects the cardiorespiratory system, hemodynamics and oxygenation. The aim of this study was to further investigate effects of AST by assessing changes in heart rate variability (HRV) indices.

\section{Methods}

Measurement in 24 adults comprised 8 minutes pre-baseline, 5 minutes recitation, 5 minutes recovery, 5 minutes recitation, and 20 minutes post-baseline. Measurements were performed for 3 different AST tasks [recitation of alliterative (RA), hexameter (RH), and prose (RP) verses] and a control task [mental arithmetic (MA) with voicing of the result] in a randomized crossover design. HRV was determined using a Medilog AR12 holter ECG. Multifractality of HRV was determined using the multifractal detrending moving average method. Statistical analysis was applied to the difference between pre-baseline, 2 recitation and 5 baseline periods. The four tasks were tested separately; $\mathrm{p} \leq 0.05$ was considered significant.

\section{Results}

(1) During recitation: Heart rate increased during RA, RH and MA but not during RP. The coefficient of variation increased during $\mathrm{RH}$ and MA. Normalized high frequency (nHF, 0.15-0.4 Hz) and low frequency (nLF, 0.04$0.15 \mathrm{~Hz}$ ) power of the HRV decreased (nHF) and increased (nLF) during RA, RH and RP. The multifractal parameter $\alpha$ mode showed a decrease during MA. The degree of multifractality $(\Delta \alpha)$ increased during PR and MA. Heart rate coherence (HRC) decreased during RP, RH and MA. (2) After recitation: PR caused an increase in $\Delta \alpha$; $H$ caused an increase in the very low frequency

${ }^{1}$ University of Bern, Institute of Complementary Medicine KIKOM , Bern, Switzerland

Full list of author information is available at the end of the article
(VLF, $<0.04 \mathrm{~Hz}$ ) power, and the HR decreased after RA and RH. HRC decreased after RH.

\section{Conclusion}

AST affects HRV indices during and after the AST. The changes indicate that AST during the recitation decreases the activity of the parasympathicus. The multifractality of HRV changed during MA and after MA and PR. The decrease in HRC after RH indicates a change in the activity of the hypothalamus-pituitary-adrenal axis.

\section{Author details}

'University of Bern, Institute of Complementary Medicine KIKOM, Bern, Switzerland. ${ }^{2}$ University Hospital Zurich, Zurich, Switzerland.

Published: 12 June 2012

doi:10.1186/1472-6882-12-S1-P236

Cite this article as: Wolf et al:: P02.180. Arts speech therapy influences heart rate variability indices. BMC Complementary and Alternative Medicine 2012 12(Suppl 1):P236.

\section{Submit your next manuscript to BioMed Central and take full advantage of: \\ - Convenient online submission \\ - Thorough peer review \\ - No space constraints or color figure charges \\ - Immediate publication on acceptance \\ - Inclusion in PubMed, CAS, Scopus and Google Scholar \\ - Research which is freely available for redistribution

